Asian Journal of Engineering and Applied Technology

ISSN: 2249-068X Vol. 7 No. S1, 2018, pp.7-10

(C) The Research Publication, www.trp.org.in

\title{
Simulation of Urban Drainage System Using a Storm Water Management Model (SWMM)
}

\author{
Vinay Ashok Rangari ${ }^{1}$, Sriramoju Sai Prashanth ${ }^{2}$, N. V. Umamahesh ${ }^{3}$ and Ajey Kumar Patel ${ }^{4}$ \\ ${ }^{1}$ Research Scholar, ${ }^{2}$ Graduate Student, ${ }^{3}$ Professor, ${ }^{4}$ Assistant Professor, \\ National Institute of Technology, Warangal, Andhra Pradesh, India \\ E-Mail: vinayrangari@gmail.com
}

\begin{abstract}
Urban floods are caused due to increase in population density, development of urban infrastructure without paying due consideration to drainage aspects and increase in paved surfaces. Storm water modelling plays an important role in checking issues such as flash floods and urban water-quality problems. The SWMM (Storm Water Management Model) has been an effective tool for simulating floods in urban areas. In this study a SWMM model is developed to analyze drainage network for the campus of National Institute of Technology, Warangal in the city of Warangal, Telangana, India. The model is simulated for one real storm event and 2-year return period of interval 1-hour design storm intensity. Frequency analysis is performed using best fitted distribution i.e., Gumbel's distribution for different return periods and the frequency values are used for development of IDF (intensity-duration-frequency) curves. Design storm intensity derived from IDF curves for different return periods is used to estimate peak runoff from each sub catchment which is used as input parameter in simulation of runoff in SWMM. GIS methodology is employed for handling spatial data simultaneously. From results, it is observed that some part of campus are commonly affected with flooding, when analysis is performed for two design storms and one day continuous rainfall/precipitation values.
\end{abstract}

Keywords: Urban Flood, Storm water, SWMM, GIS, NIT Warangal, Rainfall-Runoff Simulation

\section{INTRODUCTION}

Most of the cities in India are facing the problem of urban flooding lately. Unplanned growth of urban areas is affecting the natural drainage surface (Ahmed et al., 2013). Moreover urbanisation is responsible for sealing of ground. Thus short duration intense rainfall is resulting in high flood peak flows form altered catchments of urban areas (Suriya et al., 2012). Storm water drains play an important role in conveying the rainfall from the urban areas to the outlet point mostly a water body like river or lake (Zameer et al., 2013). The drainage network in the country is old and deteriorated and thus do not have sufficient capacity to carry excess runoff due to extreme flooding events and hence flash floods occur almost in events of short duration rainfall with high intensity (Schmitt et al., 2004). Unlike other types of flooding, urban flooding is a direct, quick and localized consequence of rainfall (Awakimjan, 2015). It often occurs with minute warning and affects areas not evidently prone to flooding which makes unpredictable and uncontrollable (NDMA Guidelines, 2010). This kind of flooding leads to heavy economic losses and disturbing social and environmental impacts (Rodriguez et al., 2005). To avoid this type of situations, it is essential to dispose of the excess water economically and efficiently in the quickest possible time. One of the ways to reduce its intensity is proper designing and maintenance of drainage system. The notable examples of urban flooding in India which caused huge loss in terms of money and human life are Hyderabad (2016), Chennai (2015), Srinagar (2014), Mumbai and Kolkata (2013) (Rafiq et al., 2016, Rangari et al., 2016). Such happenings cannot be sopped but its influence can be minimized through modeling of flood events and preparing action plans an alert system (Tate, 1999, Knebl et al., 2005).

A number of softwares are available which are capable of simulating urban floods. The first computerized models of urban storm drainage were developed during the late 1960s, and since that time a multitude of models have been in utilization (Zoppou, 2001; Mitchell, 2001). These models can be classified as design models, flow prediction models, and planning models (Rangari et al, 2015, Hunter et al., 2007). With the advent of Graphical User Interface (GUI) software like SWMM, HEC-HMS, HEC-RAS, MIKE FLOOD etc. modelling of the urban flood became easy and easily understandable outputs have been generated by these software. Geographical Information System (GIS) software like ArcGIS, QGIS etc., has made the work still simpler for extracting data for direct inputs to the model (Hasheyman et al., 2015). The availability of DEM has made the simulation to more extensive simplification of reality when data availability is less (Magesh et al., 2012).

The main aspect of flood modelling is to understand the characteristics of flood in the urban area and the impacts of heavy rainfall on the runoff of the urban catchments and the various socio-economic aspects of flood (Guangtao et al., 2011). In this study, stormwater drainage system of NIT Warangal campus is examined using environmental protection agency's (EPA) storm water management model (SWMM). The SWMM is a dynamic rainfall-runoff simulation model based on momentum, mass and energy conservation laws. This model is used in the design, analysis and planning of drainage systems and for the simulation of runoff quality and quantity in urban areas (Rossman, 2010). 


\section{A. Study Area and Data Used}

Area chosen for the present study is a small campus of NIT (National Institute Technology), Warangal. The Geographic location of the campus is $17^{\circ} 59^{\prime} \mathrm{N}$ latitude, $79^{\circ} 31^{\prime} \mathrm{E}$ longitude. The location map of the NIT, Warangal is shown in the figure 1. NIT Warangal is located in the city of Hanamkonda, Warangal which is in turn located in the northern region (slightly to east) of Telangana. The 256-acre $\left(1.04 \mathrm{~km}^{2}\right)$ residential campus is situated on either side of National Highway 202 (Hyderabad to Warangal) at a distance of $3 \mathrm{~km}$ from Kazipet Railway Station and $12 \mathrm{~km}$ from Warangal Railway Station.

Data of the study area is collected from different agencies. Most of the data regarding DEM (Digital Elevation Model) map, landuse-landcover map were extracted from Cartosat $30 \mathrm{~m}$ DEM obtained from Bhuvan. Hourly rainfall data for 33 years is procured from WMC (Warangal Municipal Corporation), while 10 years rainfall data is taken from NIT Warangal campus weather station. The drainage details and present drainage network drawings are collected from NIT campus project office.

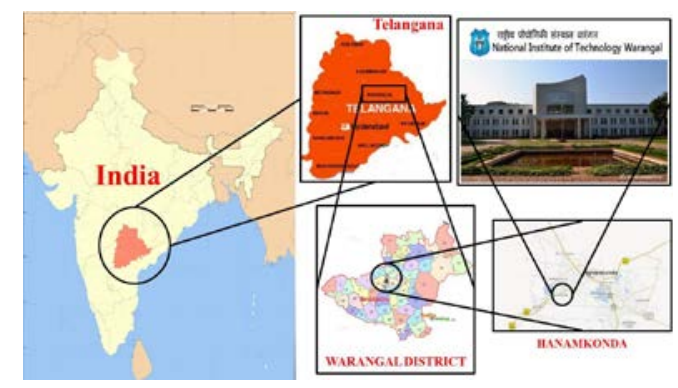

Fig. 1 Geographic Location of NIT Warangal

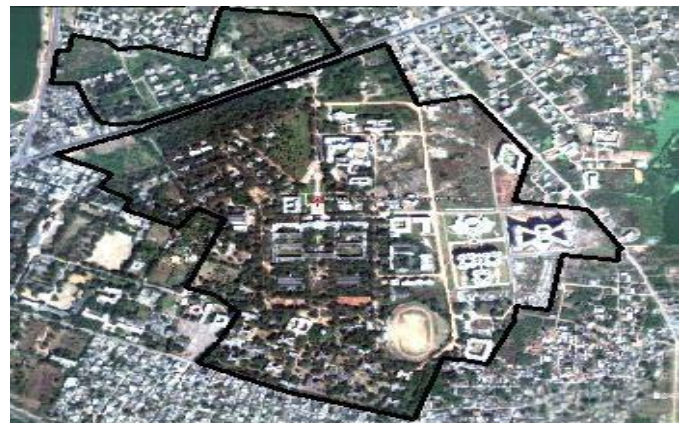

Fig. 2 Image of NIT Warangal Campus showing its boundary

\section{B. The Problem Statement}

NIT Warangal is one of India's reputed colleges. There has been development in the drainage systems corresponding to the sewage network but storms which causes surface runoff follows open drain system. A lot of construction activities and developments are taking place in the campus. Thus available permeable land is reducing. As a result, more and more runoff joining the open drains resulting in overflows at many locations. Due to heavy rainfall, lots of places get inundated in campus (especially in the low lying regions). Less maintenance of drain is also a reason for flood inundation as the capacity of the drain to carry storm has reduced over period of time. This causing many environmental problems like flooding, spreading of waterborne diseases and mosquitoes in the campus. Thus there is a need analyze and modify the drainage network of campus to carry excess of rain water and reduce the inundation.

\section{METHODOLOGY}

The Methodology consists of three parts: 1, Developing Intensity Duration Frequency (IDF) curves for the available rainfall data using best fitted distribution; 2, finding out the maximum discharge from the catchment using rational formula; and 3, carrying out capacity analysis of existing drainage system for design storm intensity considered from IDF curves.

Capacity analysis of existing drainage network for the chosen study area is carried out using well-known software SWMM (Storm Water Management Model). The models were set up using Cartosat $30 \mathrm{~m}$ DEM, LULC maps extracted from DEM and other drainage details collected from WMC. The total catchment area is divided into subbasins using ArcGIS tool. Time of concentration is estimated using Kirpich formula for each sub-basin. Design rainfall intensity is obtained from IDF curves.

\section{A. Generation of Intensity Duration Frequency (IDF)Curves}

The annual maximum daily rainfall data of 33 years collected from WMC (Warangal Municipal Corporation) and institute rain gauge is used for development of IDF curves. For the rainfall data Gumbel's distribution provided a better fit than the Log normal distribution based on Kolmogorov-Smirnov test of goodness of fit. Frequency analysis is performed using best fitted distribution i.e., Gumbel's distribution for different return periods 2year and 5year, and the frequency values are used for development of IDF Curves, which is shown in figure 3. IDF relationship is developed for all return periods from IDF curves. Design storm intensity derived for different return periods is used to estimate peak runoff from each sub catchment and input parameter in simulation of runoff from each sub catchment in SWMM.

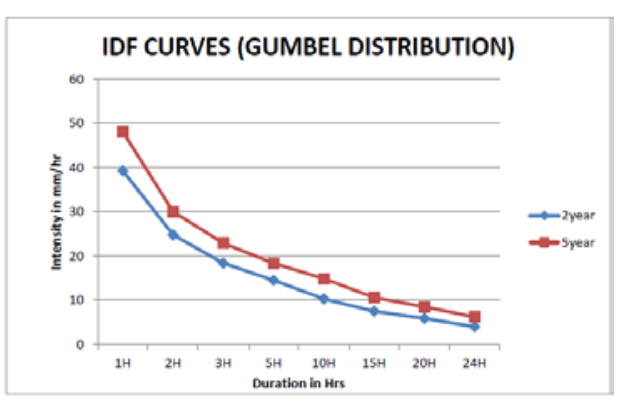

Fig. 3 Intensity-duration-frequency curves 


\section{B. Capacity Analysis of Existing Drainage System}

The SWMM model is developed for the study area as shown in below figure 4. The total study area is divided into nine sub basins by considering the drainage line in arc GIS 10.2. Land use land cover pattern for the study area is extracted from $30 \mathrm{~m}$ Cartosat DEM. Area of each sub basin is calculated and provided as input in storm water management model (SWMM) to define the runoff from each sub catchment (sub basins are considered as sub catchments in SWMM). Overland flow from each sub catchment is calculated using rational formula and SWMM model (figure 4) is simulated for the calculated flow values and flooding junctions are identified.

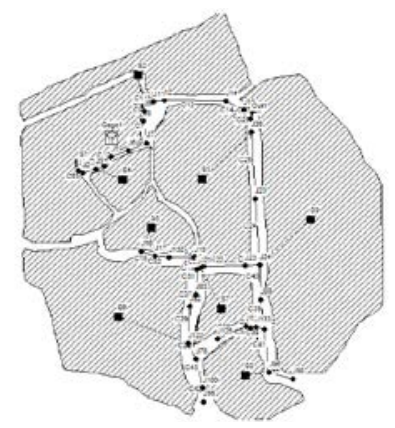

Fig. 4 SWMM model for study area

\section{RESULTS AND DISCUSSION}

Intensity of 2 year return period of 1 hour duration is considered as design intensity. The value of intensity is $39.251 \mathrm{~mm} / \mathrm{hr}$. Peak runoff for every subcatchment is calculated using rational formulae and given as input at each node/ junction from corresponding subcatchment. SWMM model is simulated for two conditions viz. design storm of 2 year return period and 1 day historical rainfall and overall simulation results are presented in table II and table III respectively. The flooding junctions are identified and presented in table 3 and table 4 . Simulation results of 2 year return period design storm shows that maximum flooding occurring at J8, J20, J22. Some conduits C3, C8, C20, C22 have attained maximum/ full depth. Flow in the channels is dependent on the conduit slope and dimensions and roughness are the factors.

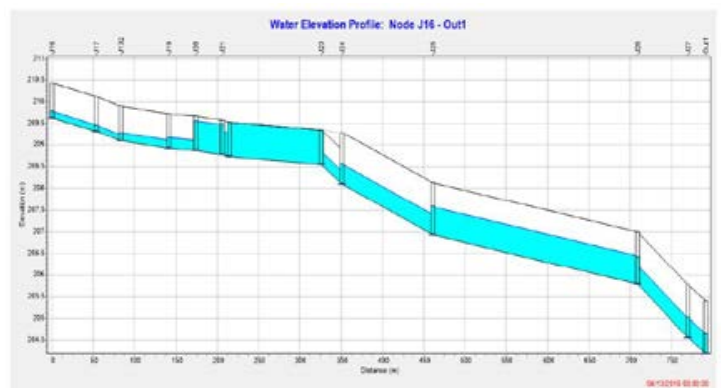

(a)

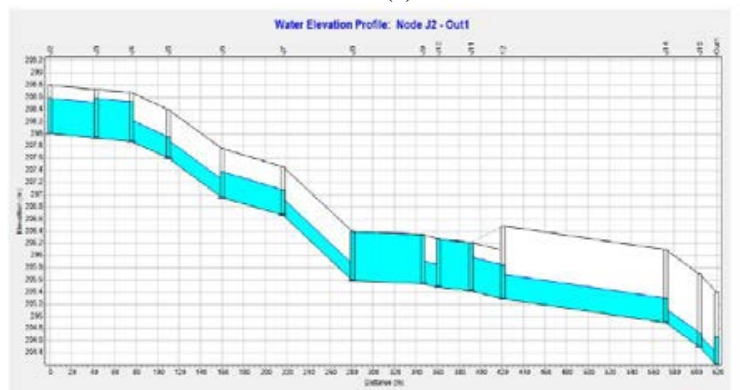

(b)

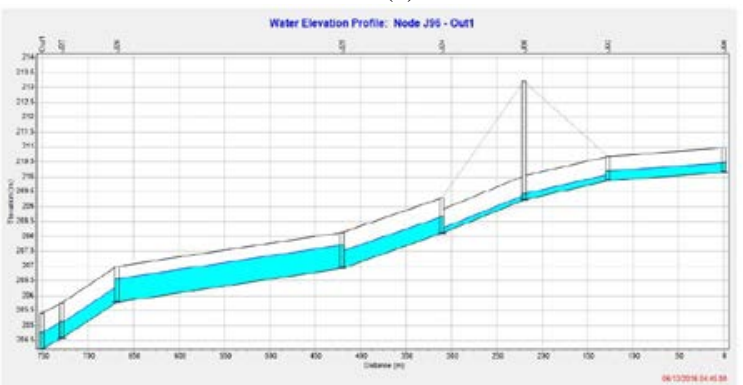

(c)

Fig. 5 Water Surface Profile at Different Junction Points

TABLE I SWMM MODEL CALCULATIONS FOR 1-HOUR DESIGN STORM INTENSITY WITH 2YEAR RETURN PERIOD

\begin{tabular}{|c|c|c|c|c|}
\hline $\begin{array}{c}\text { Return } \\
\text { period }\end{array}$ & $\begin{array}{c}\text { Flow Frequency } \\
\text { percentage }\end{array}$ & $\begin{array}{c}\text { Average } \\
\text { Flow CMS }\end{array}$ & $\begin{array}{c}\text { Maximum } \\
\text { Flow CMS }\end{array}$ & $\begin{array}{c}\text { Total volume } \\
\mathbf{1 0} \wedge \mathbf{6} \text { ltr }\end{array}$ \\
\hline $2 \mathrm{yr}$ & 100.00 & 0.492 & 4.222 & 1.799 \\
\hline
\end{tabular}

TABLE II DESCRIPTION OF STORM EVENTS RESULTING IN FLOODING FOR ONE DAY HISTORICAL RAINFALL DATA

\begin{tabular}{|c|c|c|c|c|}
\hline $\begin{array}{c}\text { Return } \\
\text { period }\end{array}$ & $\begin{array}{c}\text { Flow Frequency } \\
\text { percentage }\end{array}$ & $\begin{array}{c}\text { Average } \\
\text { Flow CMS }\end{array}$ & $\begin{array}{c}\text { Maximum } \\
\text { Flow CMS }\end{array}$ & $\begin{array}{c}\text { Total volume } \\
\mathbf{1 0} \wedge \mathbf{6} \text { ltr }\end{array}$ \\
\hline 1Day & 7.08 & 0.434 & 3.163 & 79.649 \\
\hline
\end{tabular}

TABLE III SUMMARY OF FLOODING AT JUNCTIONS FOR 1 DAY HISTORICAL DATA

\begin{tabular}{|c|c|c|c|c|}
\hline Node & Hours Flooded & $\begin{array}{c}\text { Maximum } \\
\text { Rate CMS }\end{array}$ & $\begin{array}{c}\text { Hour of } \\
\text { Maximum Flooding }\end{array}$ & $\begin{array}{c}\text { Total Flood Volume } \\
\mathbf{1 0}^{\wedge} \mathbf{6} \text { ltr }\end{array}$ \\
\hline J10 & 0.08 & 0.005 & $4: 00$ & 0.001 \\
\hline J22 & 0.85 & 0.217 & $4: 00$ & 0.34 \\
\hline J8 & 0.76 & 0.138 & $4: 01$ & 0.235 \\
\hline
\end{tabular}


TABLE IV SUMMARY OF FLOODING AT JUNCTIONS FOR 2 YEAR RETURN PERIOD DESIGN STORM INTENSITY

\begin{tabular}{|c|c|c|c|c|}
\hline Node & Hours Flooded & $\begin{array}{c}\text { Maximum } \\
\text { Rate CMS }\end{array}$ & $\begin{array}{c}\text { Hour of } \\
\text { Maximum Flooding }\end{array}$ & $\begin{array}{c}\text { Total Flood Volume } \\
\mathbf{1 0} \wedge \mathbf{6 ~ l t r}\end{array}$ \\
\hline J20 & 0.03 & 0.003 & $00: 05$ & 0.000 \\
\hline J22 & 0.07 & 0.174 & $00: 06$ & 0.028 \\
\hline J8 & 0.08 & 0.151 & $00: 08$ & 0.026 \\
\hline
\end{tabular}

\section{CONCLUSION}

In the present study a storm water drainage network for NIT Warangal campus has been analyzed using the well-known Storm water Management model. The data required for this model has been met by sources like Warangal Municipal Corporation and institute development project office. Simulation results for different design storms shows the J8, J0, J22 are commonly affected with flooding. Water surcharge conditions at junctions can be reduced by increasing the dimensions of the drainage system.

\section{REFERENCES}

[1] Z. Ahmed, D. R. M. Rao, K. R. M. Reddy and Y. E. Raj, “Urban Flooding - Case Study of Hyderabad", Global Journal of Engineering, Design and Technology, Vol. 2, No. 4, pp. 63-66, 2013.

[2] I. Awakimjan, "Urban Flood Modelling Recommendations for Ciudad Del Plata", Bachelor Thesis, University of Twente, Netherland, 2015.

[3] F. Guangtao, D. Butler, S. T. Khu and S. Sun, "Imprecise probabilistic evaluation of sewer flooding in urban drainage systems using random set theory”, Water Resources Research, Vol. 47, w02534, 2011.

[4] F. Hashemyan, M. R. Khaleghi and M. Kamyar, "Combination of HEC-HMS and HEC-RAS models in GIS in order to simulate flood (Case study: Khoshke Rudan river in Fars province, Iran)”, Res. J. Recent Sci., Vol. 4, No. 8, pp. 122-127, 2015.

[5] N. M. Hunter, "Benchmarking 2D hydraulic models for urban flooding”, Water Management, Vol. 161, Issue WM1, 2007.

[6] N. S. Magesh, and N. Ch, "A GIS Based Automated Extraction Tool for the Analysis of Basin Morphometry, Bonfring”, International Journal of Industrial Engineering and Management Science, Vol. 2(Special Issue Special Issue on Geospatial Technology Development in Natural Resource and Disaster Management), pp. 32-35, 2012.

[7] M. R. Knebl, et al. "Regional scale flood modeling using NEXRAD rainfall, GIS, and HEC-HMS/RAS: a case study for the San Antonio
River Basin Summer 2002 storm event”, Journal of Environmental Management, Vol. 75, pp. 325-336, 2005.

[8] Mitchell et al. (2007). "State of the art review of integrated urban water Models”, NOVATECH 2007, 6th Int. Conf. on Sustainable Techniques and Strategies in Urban Water Management, Lyon, Rhone-Alpes, France, 25-28 June 2007.

[9] National Disaster Management (NDM) Guidelines, Management of urban flooding, A publication of: National Disaster Management Authority Government of India, 2010.

[10] F. Rafiq, S. Ahmed and A. A. Khan, "Urban floods in India", International Journal of Scientific \& Engineering Research, Vol. 7, Issue 1, pp. 721- 734, 2016.

[11] V. A. Rangari, K. V. Gopi, N. V. Umamahesh, and A. K. Patel., "Simulation of urban drainage system using disaggregated rainfall data”, ICWEES Int. Conf. on Water Environment, Energy \& Society2016, Organized By Texas A \& M University, USA \& AISECT University, Bhopal, India, 15-18 March, 2016.

[12] V. A. Rangari, A. K. Patel and N. V. Umamahesh, "Review of urban stormwater models", HYDRO 2015, 20th Int. Conf. on Hydraulics, IIT Roorkee, India, 2015.

[13] L. A. Rossman, "Storm water management model user's manual", USEPA Software, 2010.

[14] T. G. Schmitt, M Thomas and N Ettrich, "Analysis and modeling of flooding in urban drainage systems”, Journal of Hydrology, Vol. 299, Issues 3-4, 2004. [Online]. Available: https://doi.org/10.1016/j.jhydrol.2004.08.012.

[15] S. Suriya and B. V. Mudgal, "Impact of urbanization on flooding: The Thirusoolam sub watershed - A case study", Journal of Hydrology, pp. 412-413, pp. 210-219, 2012.

[16] E. Tate, "Floodplain mapping using HEC-RAS and ArcView GIS", CRWR Online Report, pp. 99-1, 1999. [Online]. Available: http://www.ce.utexas.edu/centers/crwr/reports/online.html.

[17] C. Zoppou "Review of urban storm water models", Environmental Modelling and Software, Vol. 16, pp. 195-231, 2001.

[18] F. Rodriguez, C. Cudennec and H. Andrieu, "Application of morphological approaches to determine unit hydrographs of urban catchments”, Hydrological Processes, Vol. 19, No. 5, pp. 1021-1035, 2005.

[19] EPA SWMM 5.1. [Online]. Available: https://www.epa.gov/waterresearch/storm-water-management-model-swmm. 